\title{
Obtention d'embryons par culture d'anthères chez le chou-fleur et le brocoli et évaluation des potentialités du matériel obtenu pour la création variétale
}

\author{
JE Chauvin 1 *, Q Yang 2, B Le Jeune ${ }^{3}$, Y Hervé 2 \\ 1 INRA/GIP, "Prince de Bretagne Biotechnologie", Penn Ar Prat, F29250 Saint-Pol-de-Léon; \\ 2 INRA, Centre de Rennes, Station de génétique et d'amélioration des plantes, domaine de la Motte, F35650 Le Rheu; \\ ${ }_{3}$ INRA, Centre de Rennes, ferme de Kerdevez, Laboratoire d'amélioration des plantes maraîchères, \\ F29250 Saint-Pol-de-Léon, France
}

(Reçu le 9 septembre 1992; accepté le 19 mai 1993)

\begin{abstract}
Résumé - Des cultures d'anthères ont été réalisées sur 20 génotypes de chou brocoli (Brassica oleracea ssp italica) et 10 génotypes de chou-fleur ( $B$ oleracea ssp botrytis). Le nombre d'embryons androgénétiques obtenus dépend du génotype. Le milieu de culture des anthères conduisant au meilleur rendement est un milieu liquide contenant du nitrate d'argent. Le taux d'obtention de plantules à partir des embryons varie avec le stade de développement de l'embryon au moment du repiquage et la teneur du milieu en saccharose. Le niveau de plö̈die des plantes acclimatées en serre a été analysé par cytométrie en flux et traduit des phénomènes précoces de polyploïdisation plus ou moins marqués selon les génotypes. Les lignées diploïdes issues de ces travaux présentent, en général, des rendements en graines faibles par rapport aux plantes issues des procédés habituels de production de lignées par autofécondation. L'intérêt de la culture d'anthères comme outil de création de lignées dans le cadre des programmes d'amélioration des crucifères légumières est discuté.
\end{abstract}

Brassica oleracea ssp italica $=$ brocoli $/$ B oleracea ssp botrytis $=$ chou-fleur $/$ culture d'anthères $/$ niveau de ploïdie / fertilité

Summary - Androgenic embryos obtained by anther culture of Brassica oleracea (ssp italica and ssp botrytis) and estimation of the value of regenerated material in plant breeding programs. Anther culture was undertaken on 20 broccoli and 10 cauliflower genotypes. The androgenic embryo yield depended on the variety, on the genotype and on the culture medium. The best results were obtained with a liquid medium containing silver nitrate. The regeneration rate from embryos to plantlets changed according to the embryo developmental stage at the time of subculture and according to sucrose concentration in the medium. The ploidy level of acclimated plantlets was determined by flow cytometry of nuclei and showed early polyploidization dependent on donor genotype. In general, the diploid lines derived from this work give very low seed yields compared with the lines derived from classical selection methods. The interest of utilizing anther culture in the creation of lines for broccoli and cauliflower breeding programs is discussed.

Brassica oleracea ssp italica $=$ broccoli $/$ B oleracea ssp botrytis $=$ cauliflower $/$ anther culture $/$ ploidy level $/$ fertility

* Correspondance et tirés à part à l'adresse suivante : INRA, domaine de Keräiber, Pomme de terre/plantes à bulbes, 29260 Ploudaniel, France 


\section{INTRODUCTION}

La création de lignées homozygotes est un préalable indispensable à l'obtention de variétés hybrides $\mathrm{F} 1$ dans le cadre des programmes d'amélioration des crucifères légumières. Les techniques d'autofécondation ou les croisements frères-sœurs permettent de se rapprocher de l'état homozygote souhaité tout en autorisant une élimination progressive des génotypes dont l'aptitude à la combinaison se montre mauvaise lors de tests réalisés dès la deuxième ou troisième génération obtenue par autofécondation. Cependant, ces schémas sont relativement longs à mettre en œuvre car il faut théoriquement 8 à 12 autofécondations successives pour atteindre un état proche de l'homozygotie, ce qui peut représenter jusqu'à 16 à 24 ans pour des cultigroupes bisannuels comme les choux-fleurs, Brassica oleracea ssp botrytis, ou les brocolis, $B$ oleracea ssp italica, de type hiver.

Dans ce contexte, les travaux engagés par un certain nombre de chercheurs japonais, européens et américains sur les possibilités d'obtention de plantes haploïdes pour les 2 sousespèces $B$ oleraceae ssp italica et ssp botrytis par culture d'anthères (Keller et Armstrong, 1983 ; Orton et Browers, 1985; Ockendon, 1988 ; Yang, 1989 ; Arnison et Keller, 1990 ; Arnison et al, 1990a et b; Phippen et Ockendon, 1990) ou par culture de microspores (Lichter, 1989 ; Takahata et Keller, 1991 ; Duijs, 1992) revêtent une grande importance. En effet, après doublement, naturel ou provoqué, du stock chromosomique de ces plantes, on obtient des individus d'origine androgénétique dits haploïdes doublés (HD), qui peuvent éventuellement être utilisés dans les programmes de sélection comme parents d'hybrides. Ces HD présentent, dans le cas du chou-fleur et du brocoli de type hiver, des intérêts théoriques indéniables: homozygotie atteinte en 1 cycle de culture, soit 6 à 9 mois au lieu des 16 ans nécessaires par le biais des autofécondations, possibilités d'étude du déterminisme génétique de différents caractères agronomiques comme la stérilité mâle, l'auto-incompatibilité, la résistance aux parasites.

Toutefois, pour pouvoir développer des schémas de sélection du chou-fleur et du brocoli basés sur l'utilisation de lignées HD, il faut que la technique d'haplodiploïdisation réponde à 3 critères au moins : 1) bonne production d'embryons haploïdes ; 2) facilité du passage de l'état haploïde à l'état diploïde; 3) grand nombre de gé- notypes réactifs. Cet article présente les résultats les plus récents obtenus dans notre laboratoire en matière d'androgenèse sur chou-fleur et brocoli et souligne les principales difficultés encore rencontrées en ce qui concerne ces 3 points.

\section{MATÉRIEL ET MÉTHODES}

\section{Matériel végétal}

Les plantes-mères ont été conduites dans les conditions que nous avions définies comme étant les plus favorables pour les cultures d'anthères (Yang et al, 1992a) ; en particulier, les plantes sont élevées dans une serre dont la température est maintenue entre 15 et $20^{\circ} \mathrm{C}$.

Vingt génotypes de chou brocoli, dont 15 variétés hybrides commerciales (tableau 1), et 10 génotypes de chou-fleur sélectionnés par le laboratoire d'amélioration des crucifères légumières du centre de recherches INRA de Rennes ont servi de support à cette étude. La nature de ces génotypes - lignées, hybrides ou individus clonés issus de population - est indiquée dans le tableau I. Quatre à 6 plantes obtenues par bouturage pour chaque génotype ont été cultivées en serre.

\section{Culture d'anthères}

Des boutons de petite taille (4 à $6 \mathrm{~mm}$ selon le génotype) ont été prélevés sur les différentes plantesmères pour un même génotype. À ce stade de développement, des études cytologiques préalables ont permis de montrer que la majorité des microspores est sur le point de subir la première mitose pollinique. Les mises en culture sont réalisées selon la technique décrite antérieurement (Yang et al, 1992a) sur le même milieu de base. Celui-ci contient toutefois seulement $0,29 \mathrm{~mol} / \mathrm{l}$ de saccharose pour le brocoli alors qu'il contient $0,41 \mathrm{~mol} / \mathrm{l}$ de saccharose pour le chou-fleur, des essais préliminaires ayant permis de vérifier que ces concentrations étaient les plus adaptées pour l'une et l'autre des sous-espèces.

Les essais au cours de cette étape ont concerné l'emploi de milieu liquide et l'effet de l'adjonction de nitrate d'argent. Ainsi, les anthères ont été déposées dans des boîtes de Pétri dont le diamètre est de $55 \mathrm{~mm}$ contenant soit $4 \mathrm{ml}$ de milieu de base liquide, soit ce même milieu solidifié avec $7 \mathrm{~g} / \mathrm{l}$ d'agarose (Sigma, type II-A: medium EEO). Dans une série expérimentale en milieu solide, différentes concentrations en $\mathrm{AgNO}_{3}(0,059 ; 0,368 ; 0,736$ et $1,472 \mathrm{mmol} / \mathrm{l})$ ont été essayées. Le protocole qui suit la mise en culture n'a pas été modifié par rapport à celui suivi par Yang et al (1992a). 
Tableau I. Réponse à la culture d'anthères, en nombre d'embryons produits pour 100 anthères mises en culture, pour différents génotypes chez Brassica oleracea dans la sous-espèce italica et dans la sous-espèce botrytis : résultats obtenus sur les milieux les plus performants.

$\begin{array}{ll}\text { Sous-espèce } & \begin{array}{l}\text { Nature des Nombre Groupes } \\ \text { sénotype }\end{array} \\ \text { structures d'embryons homogènes } \\ \text { génétiques pour } 100 \\ \text { anthères } \\ \text { enculture }\end{array}$

ssp italica (milieu défini par Keller et Armstrong (1983) liquide et avec $0,368 \mathrm{mmol} / / \mathrm{AgNO}$ )

$\begin{array}{llrc}\text { Green Duke } & \text { hybride F1 } & 2082 & \text { A } \\ \text { Légende } & \text { hybride F1 } & 482 & \text { B } \\ \text { Arcadia } & \text { hybride F1 } & 315 & \text { B } \\ \text { Shogun } & \text { hybride F1 } & 135 & \text { C } \\ \text { Scorpio } & \text { individu cloné } & 122 & \text { C } \\ \mathrm{n}^{\circ} 53 & \text { hybride F1 } & 116 & \mathrm{C} \\ \mathrm{Skiff} & \text { hybride F1 } & 99 & \mathrm{C} \\ \mathrm{n}^{\circ} 115 & \text { hybride F1 } & 68 & \mathrm{C} \\ \text { Emerald } & \text { hybride F1 } & 66 & \mathrm{C} \\ \text { Green Belt } & \text { hybride F1 } & 57 & \mathrm{C} \\ \text { Samouraï } & \text { hybride F1 } & 43 & \mathrm{C} \\ \text { Ninja } & \text { hybride F1 } & 35 & \mathrm{C} \\ \mathrm{n}^{\circ} 55 & \text { hybride F1 } & 28 & \mathrm{C} \\ \text { Marathon } & \text { hybride F1 } & 15 & \mathrm{CD} \\ \text { Gem } & \text { individu cloné } & 0 & \mathrm{D}\end{array}$

Moyenne brocoli $\quad 244 \pm 135$

ssp botrytis (milieu défini par Yang et al en 1992a liquide et avec 0,736 mmol/l AgNO3)

$\begin{array}{llrl}\text { V23.2 } & \text { individu cloné } & 592 & \text { B } \\ \text { RH702 } & \text { hybride F1 } & 48 & \text { C } \\ \text { Ju 39.6 } & \text { individu cloné } & 50 & \text { C } \\ \text { J 2.19.1.5 } & \text { lignée S6 } & 33 & \text { C } \\ \text { RH703 } & \text { hybride F1 } & 18 & \text { CD } \\ 938.21 .8 & \text { lignée S6 } & 10 & \text { CD } \\ 870.14 .19 & \text { lignée S4 } & 8 & \text { CD } \\ 7.339 \times 48.9 & \text { hybride F1 } & 2 & \text { D } \\ \text { F 45.21.10 } & \text { lignée S2 } & 2 & \text { D } \\ 7.339 .6 .13 \mathrm{~A} & \text { lignée S8 } & 0 & \text { D }\end{array}$

Moyenne chou-fleur

$76 \pm 58$ ou $0,175 \mathrm{~mol} / \mathrm{l})$. Le milieu est solidifié avec $7,5 \mathrm{~g} / \mathrm{l}$ d'agar (Merck, agar-agar). Les embryons ont été mesurés au moment du repiquage et 3 groupes ont été constitués : i) embryons de 1 à $1,5 \mathrm{~mm}$; ii) embryons de 2 à $5 \mathrm{~mm}$; iii) embryons de plus de $6 \mathrm{~mm}$.

Après repiquage en tubes, les embryons ont été placés dans une enceinte climatisée dont la photopériode est de $16 \mathrm{~h}$ (éclairement de l'ordre de $50 \mu \mathrm{mol} /$ $\mathrm{m}^{2} \mathrm{~s}$ ) pour $8 \mathrm{~h}$ d'obscurité. Après $4 \mathrm{sem}$, les plantules sont repiquées en tubes, ou sorties sous miniserres (Éts Bouillard Frères) si leur développement radiculaire et foliaire est suffisant, dans un terreau préalablement désinfecté à la vapeur. Les miniserres sont elles-mêmes installées dans des serres où la température est comprise entre 15 et $20^{\circ} \mathrm{C}$.

Une fois acclimatés, les plants ont été repiqués en pots puis en conteneurs et maintenus dans une serre pendant tout le cycle végétatif et la période de floraison.

\section{Évaluation du niveau de ploïdie}

Sur les jeunes plantes acclimatées en serre, la détermination du niveau de ploïdie a été réalisée, compte tenu du pourcentage très élevé de plantes polyploïdes que nous avions pu détecter lors d'études précédentes (Boucault et al, 1991). Les effectifs dans chaque descendance étant relativement importants, nous avons employé une technique de cytométrie en flux qui permet des analyses en série avec un protocole relativement facile à mettre en œuvre (Brown et al, 1991a).

Un fragment de jeune feuille d'environ 3 à $4 \mathrm{~cm}^{2}$ est prélevé sur les plantes en serre au stade végétatif. II est déposé dans une boîte de Pétri et haché à l'aide d'une lame de rasoir dans $2 \mathrm{ml}$ de tampon de ploïdie (Société Chemunex) à $4^{\circ} \mathrm{C}$. Le liquide est filtré sur une membrane de porosité $30 \mu \mathrm{m}$. On ajoute au filtrat, contenant essentiellement les noyaux cellulaires en suspension, $2 \mu$ le colorant de Hoechst (excitation : $365 \mathrm{~nm}$, émission: $455 \mathrm{~nm}$ ), spécifique des liaisons adénine-thymine de l'ADN. L'échantillon ainsi préparé est maintenu 5 min environ dans de la glace pilée puis passé au cytomètre de flux (Chemflow, Société Chemunex) en travaillant dans le proche ultraviolet.

Avec cette technique, la zone de variation d'un pic définissant un niveau de ploïdie donnée se situe dans un intervalle de confiance $(P=0,95)$ de $\pm 8 \%$ (Brown et al, 1991b), ce qui permet de détecter des variations de quantité d'ADN de l'ordre de $8 \%$ qui correspondent grossièrement à 1,4 chromosome pour les choux $(2 n=18)$. En introduisant une référence interne diploïde dans chaque échantillon, et en réalisant des analyses répétées sur certains individus, des aneuploïdies peuvent être détectées.

\section{Culture des embryons, acclimatation en serre et conduite des plantes obtenues}

\footnotetext{
sont repiqués en tubes sur un milieu $\mathrm{B}_{5}$ (Gamborg et al, 1968) sans régulateur de croissance au sens strict mais additionné de $0,39 \mathrm{mmol} / \mathrm{l}$ de sulfate d'adénine et contenant différentes quantités de saccharose $(0,058 ; 0,117$

Les embryons apparus après 4 à 5 semaines de culture
}

\section{Fertilité et rendement en graines}

Le niveau de fertilité mâle des plantes a été évalué par observation au microscope photonique de grains 
de pollen après l'anthèse. Ceux-ci sont montés entre lame et lamelle dans une goutte de carmin acétique et sont supposés se colorer en rouge rosé lorsqu'ils sont viables. Le nombre de grains de pollen vivants pour 100 grains observés a été ainsi déterminé.

Les niveaux de fertilité femelle de certaines descendances ont pu être appréciés sur un échantillon d'individus pris au hasard dans chaque descendance et pour lesquels ont été comptés :

- le nombre de graines obtenues par autofécondation sur 15 fleurs avant l'anthèse (FA1) et après l'anthèse (FA2) ;

- le nombre de graines obtenues après pollinisation de 15 fleurs préalablement castrées par le pollen d'une plante utilisée comme testeur mâle (FX) ;

- le nombre de graines obtenues par pollinisation libre (FXAB) tout au long de la floraison.

Ces données ont été comparées avec les résultats de manipulations similaires entreprises au même moment sur les lignées en cours de fixation par autofécondation (sélection généalogique).

\section{Expression des résultats et traitement statistique des données}

En ce qui concerne la culture d'anthères, le nombre d'embryons formés pour chaque répétition de 10 boîtes contenant chacune 18 anthères a été enregistré à la fin de la $5^{\mathrm{e}}$ sem de culture. Les résultats sont exprimés en nombre d'embryons formés pour 100 anthères mises en culture. Une transformation logarithmique a permis une analyse de variance sur l'ensemble des données (hétérogénéité des variances).

Le taux d'obtention de plantules est calculé pour chaque traitement comme le rapport du nombre d'embryons se développant directement - sans passer par une étape d'organogenèse secondaire - sur le nombre d'embryons repiqués.

La fréquence des niveaux de ploïdie dans les descendances dont les effectifs sont supérieurs à 30 est exprimée en pourcentage. Les différentes répartitions observées dans les groupes de niveau de ploïdie ont été comparées à l'aide du test du $\chi^{2}$.

\section{RÉSULTATS ET DISCUSSION}

\section{Obtention d'embryons}

\section{Effet du génotype}

Même sur les milieux les mieux adaptés à chacune des sous-espèces, nous observons une différence entre le chou-fleur et le brocoli. Chez le brocoli, les résultats sont globalement beaucoup plus élevés : le nombre de génotypes présentant une réaction positive est plus important et les rendements observés chez les génotypes les plus "réactifs" de la variété botrytis sont équivalents aux rendements des variétés moyennement «réactives» dans la variété italica (tableau I).

Au sein de chaque sous-espèce, on peut classer les génotypes en 3 catégories selon leur aptitude à l'androgenèse : génotypes très "réactifs", génotypes moyennement "réactifs", génotypes peu ou pas "réactifs" (tableau I). Cet effet génotypique, déjà souligné par différents auteurs (Ockendon, 1985 ; Fuller et Turton, 1990), constitue une première limite à l'application de la technique d'haplodiploïdisation dans le schéma de création variétale de ces crucifères légumières, une sélection des seuls génotypes ayant une réaction positive en androgenèse pouvant introduire un biais dans le schéma général et une perte de variabilité génétique, certains allèles pouvant, de surcroît, être favorisés par le passage in vitro (Boucault et al, 1991). Ce biais sera d'autant plus important que le nombre de génotypes "réactifs" sera restreint au départ.

\section{Milieu de culture}

\section{Effet de l'emploi d'un milieu liquide}

On note de façon globale une différence entre milieu solide et milieu liquide pour la formation d'embryons (tableau II). Chez le brocoli, pour les 5 génotypes «Emerald», "Green Duke», "Green Belt», «53» et «55», le nombre moyen d'embryons produits pour 100 anthères mises en culture est de 8,7 en milieu solide alors qu'il est de 115 en milieu liquide. Cet effet est peut-être moins spectaculaire chez le chou-fleur mais reste significatif (test $t, P<0,05$ ), les rendements étant augmentés d'un facteur 2 à 3 (tableau II).

Une interaction "génotype $x$ type de milieu: solide ou liquide", quoique non décelable dans nos conditions expérimentales, doit être envisagée compte tenu des résultats négatifs obtenus par Phippen et Ockendon (1990) en travaillant sur chou-fleur avec des milieux liquides. II est important de souligner que l'utilisation de ce type de milieu a favorisé une amélioration des rendements mais n'a pas permis d'obtenir des résultats avec des génotypes non "réactifs". Ainsi, on peut penser que le milieu liquide permet un meilleur développement des structures embryonnaires (peut-être du fait d'une meilleure assimilation des éléments) mais reste sans effet sur les mécanismes d'induction de l'embryogenèse. 
Tableau II. Effet de l'utilisation d'un milieu liquide ou d'un milieu solide sur le rendement en embryons (milieu sans nitrate d'argent).

Nombre d'embryons formés pour 100 anthères en culture

\section{Milieu solide Milieu liquide}

\section{ssp italica \\ Green Duke \\ $n^{\circ} 53$ \\ Emerald \\ Green Belt \\ $n^{\circ} 55$}

Moyenne brocoli

$8,7 \pm 2,7$
370,9

45,2

79,4

44,1

37,6

$115,4 \pm 64,3$

\section{ssp botrytis \\ $\mathrm{RH} 702$}

V23.2

Moyenne chou-fleur Moyenne générale

$\begin{array}{cc}13,6 & 48,4 \\ 18,1 & 48,2 \\ & \\ 5,8 \pm 2,2 & 48,3 \pm 0,1 \\ 0,8 \pm 2,3 & 96,3 \pm 46,1\end{array}$

L'observation des boîtes en cours de culture montre que certaines anthères flottant sur le milieu se regroupent entre elles. Ce regroupement provoque parfois une sénescence précoce des tissus de l'anthère du fait de l'accumulation de produits toxiques autour des explants (HeberleBors, 1985). Ces tissus sénescents ne sont pas favorables à l'établissement de processus embryogènes (Maheshwari et al, 1980). Ainsi, l'agitation du milieu de culture pendant la phase d'incubation pourrait permettre d'augmenter encore les rendements.

\section{Effet du nitrate d'argent}

L'addition de nitrate d'argent dans le milieu, qui s'était déjà révélée intéressante dans le cas de la culture d'anthères du chou de Bruxelles (Biddington et al, 1988), a amélioré de façon sensible la production d'embryons qui se trouve en général multipliée par 2 par rapport au témoin, pour le chou-fleur comme pour le brocoli. Nous notons une augmentation des rendements lorsque la concentration en nitrate d'argent augmente dans le milieu jusqu'à une concentration optimale, valeur au-delà de laquelle les résultats enregistrés baissent de nouveau (fig 1).

Les tendances sont identiques pour les 2 sous-espèces avec des seuils optimaux différents selon le génotype considéré. Cette interac-

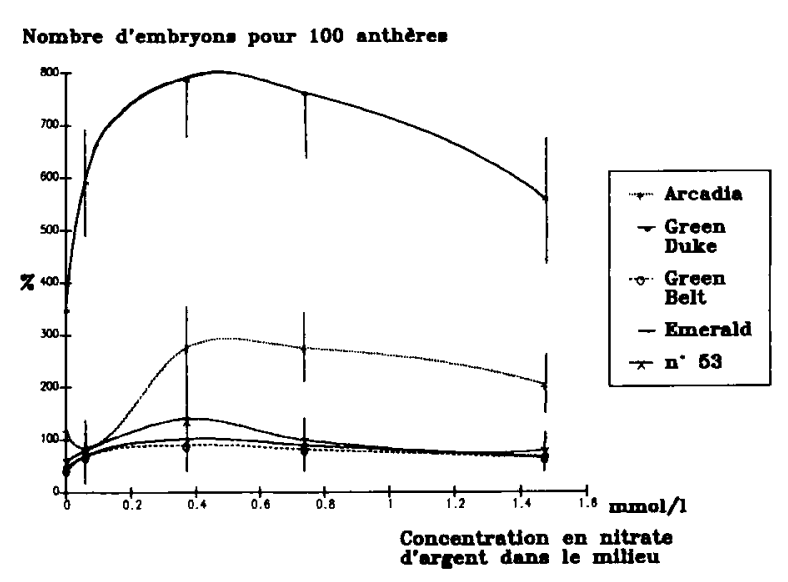

Fig 1. Effet de la concentration en nitrate d'argent dans le milieu de culture sur le nombre d'embryons obtenus pour 100 anthères mises en culture chez le brocoli (milieu solide).

tion "génotype $x$ teneur optimale en nitrate d'argent" rend indispensable l'utilisation de plusieurs milieux de culture lorsque l'on travaille sur un génotype dont on ne connaît pas le comportement in vitro. Les mêmes remarques pourraient être faites en ce qui concerne les teneurs en auxines - et notamment en 2,4-D - l'importance des chocs thermiques et le stade de développement des microspores au moment de la mise en culture des anthères pour lesquels les niveaux optimaux varient avec le génotype (Yang, 1989 ; Yang et al, 1992a et b). Ces interactions «génotype $x$ méthode" qui se retrouvent dans l'étude de l'effet de nombreux facteurs et dont les niveaux sont parfois loin d'être négligeables, constituent, dans l'état actuel de nos connaissances, un deuxième frein à l'utilisation de la technique de culture d'anthères comme outil privilégié de création de lignées, compte tenu du grand nombre de génotypes que les sélectionneurs souhaiteraient rendre homozygotes le plus rapidement possible.

L'utilisation de nitrate d'argent a permis d'obtenir des résultats sur des génotypes jugés jusque-là non «réactifs», et ce notamment chez le chou-fleur. Le rôle du nitrate d'argent, qui semble intervenir sur les mécanismes d'induction de l'embryogenèse, pourrait être lié à son pouvoir d'inhibition de l'action de l'éthylène produit par les explants en cours de culture (Beyer, 1976), éthylène qui est considéré, à partir d'une certaine concentration, comme un composé pouvant bloquer les phénomènes d'organogenèse et d'embryogenèse in vitro. Des études sur l'effet d'un apport d'éthylène d'origine exogène 
ou d'éthéphon sur les anthères en culture pourraient permettre d'apporter des éléments de réponse.

\section{Régénération de plantules}

Après 4 à 5 sem, les structures embryonnaires apparues dans les boîtes ont des stades de développement très différents: globulaire, cordiforme, torpille, cotylédonaire (fig 2a), comme cela a été déjà observé et discuté pour le chou à choucroute (Doré et Boulidard, 1988). Le problème du moment optimum pour le repiquage des embryons se pose afin d'obtenir un développement direct en plantules (fig $2 b$ ) en évitant le blocage de l'embryon ou la mise en place d'une organogenèse secondaire.

Les embryons compris entre 2 et $5 \mathrm{~mm}$ donnent des taux de développement direct 2 fois supérieurs par rapport aux autres structures embryonnaires (tableau III). La taille de l'embryon au moment de son repiquage a donc un retentissement sur ses aptitudes à se développer en une plante entière de façon directe. Le développement harmonieux des embryons est également influencé par la teneur du milieu de repi-

a

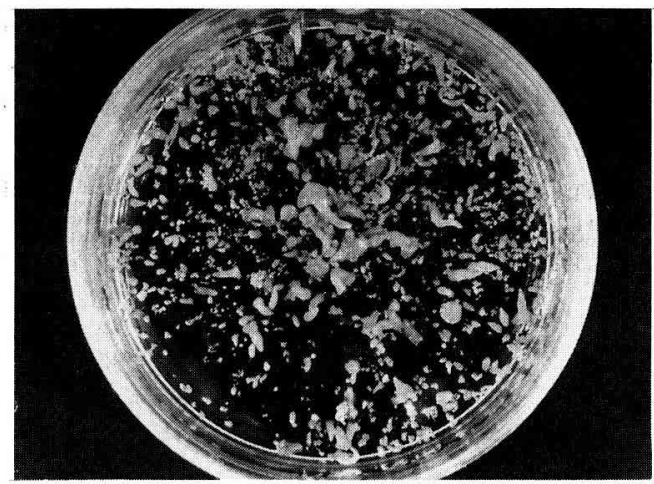

b

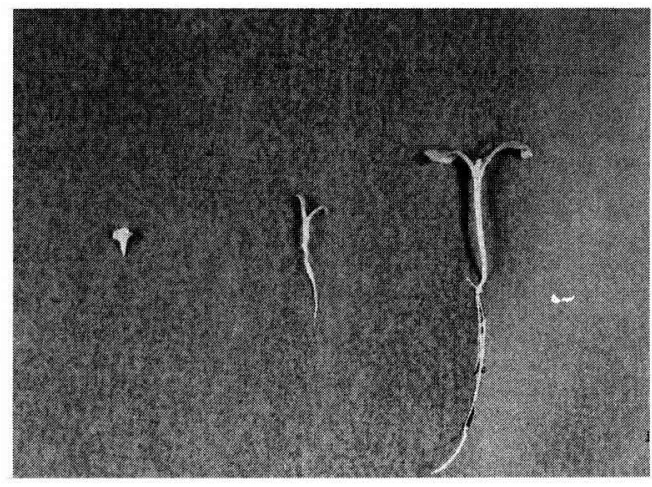

Fig 2. a. Variabilité des structures embryonnaires obtenues après 4 à 5 sem de culture en milieu liquide (Brassica oleracea ssp italica cv "Green Duke»). b. Processus de développement direct d'un embryon obtenu par culture d'anthères.
Tableau III. Effet de la taille des embryons au moment de leur repiquage sur un milieu de Gamborg sans hormone sur le taux de développement direct des embryons androgénétiques en plantules. Exemple de la variété de brocoli “Green Duke» pour laquelle 100 embryons ont été mesurés et repiqués pour chacune des 3 classes.

$\begin{array}{cc}\text { Taille de l'embryon } & \text { Taux de } \\ \text { et stade dominant } & \begin{array}{c}\text { Classes } \\ \text { développement homogènes } \\ \text { moyen }\end{array}\end{array}$

1 à $1,5 \mathrm{~mm}$ globulaire

6,3

15,5

2 à $5 \mathrm{~mm}$ torpille

7,9

B

Plus de $6 \mathrm{~mm}$ cotylédonaire

quage en saccharose, la concentration optimale se situant entre 0,058 et $0,117 \mathrm{~mol} / /$ (fig 3 ).

Le taux de développement direct au premier repiquage reste toutefois relativement faible de l'ordre de $20 \%$ dans les meilleures conditions -, et les études visant à l'amélioration de cette étape devront être poursuivies. Si l'emploi d'acide $\alpha$-naphtalène acétique (ANA) ou de 6benzyl-amino-purine (BAP) s'est montré inefficace (données non publiées), des essais d'adjonction d'acide gibbérellique (GA3) au milieu (Renard, communication personnelle), de traitement au froid (Kott et Beversdorf, 1990) ou l'utilisation de dioxyde de carbone (Yomoda et Hinata, 1991) pourraient se révéler fructueux.

\section{Acclimatation en serre}

Les pourcentages de plantes acclimatées oscillent entre 95 et $100 \%$, si la température est

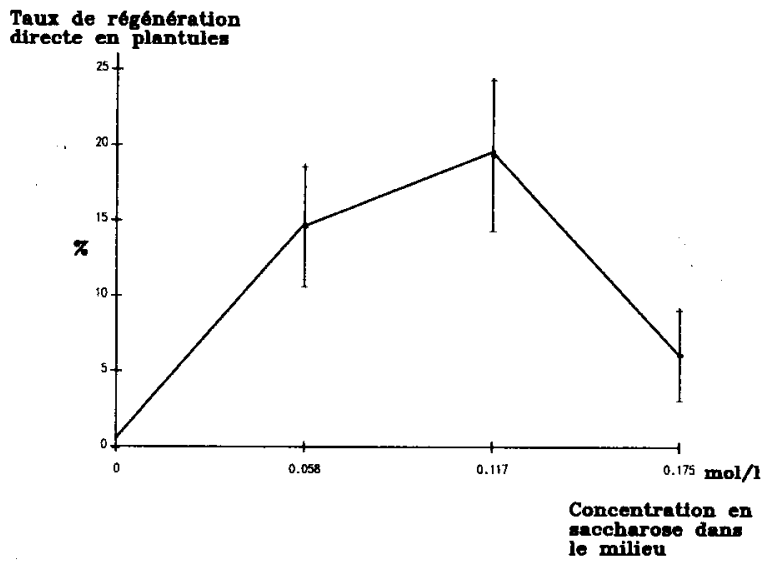

Fig 3. Effet de la teneur en saccharose du milieu de repiquage des embryons sur le taux de développement direct des embryons androgénétiques en plantules. 
maintenue entre 15 et $20^{\circ} \mathrm{C}$ et à condition que le développement radiculaire des plants avant sortie du tube soit satisfaisant (plus de 5 racines par plant).

\section{Étude du niveau de ploïdie des plantes obtenues}

Pour des échantillons de choux-fleurs et de brocolis ayant un même niveau de ploïdie, on obtient par cytométrie en flux des histogrammes très comparables, ce qui permet de penser qu'il y a peu de variation dans les teneurs en ADN des noyaux d'une sous-espèce à l'autre. La technique de cytométrie que nous avons employée permet de différencier aisément des individus n'ayant pas le même niveau de ploïdie (fig 4).

Sur l'ensemble des individus d'origine androgénétique observés, nous avons pu mettre en évidence des individus haploïdes, diploïdes, tri-

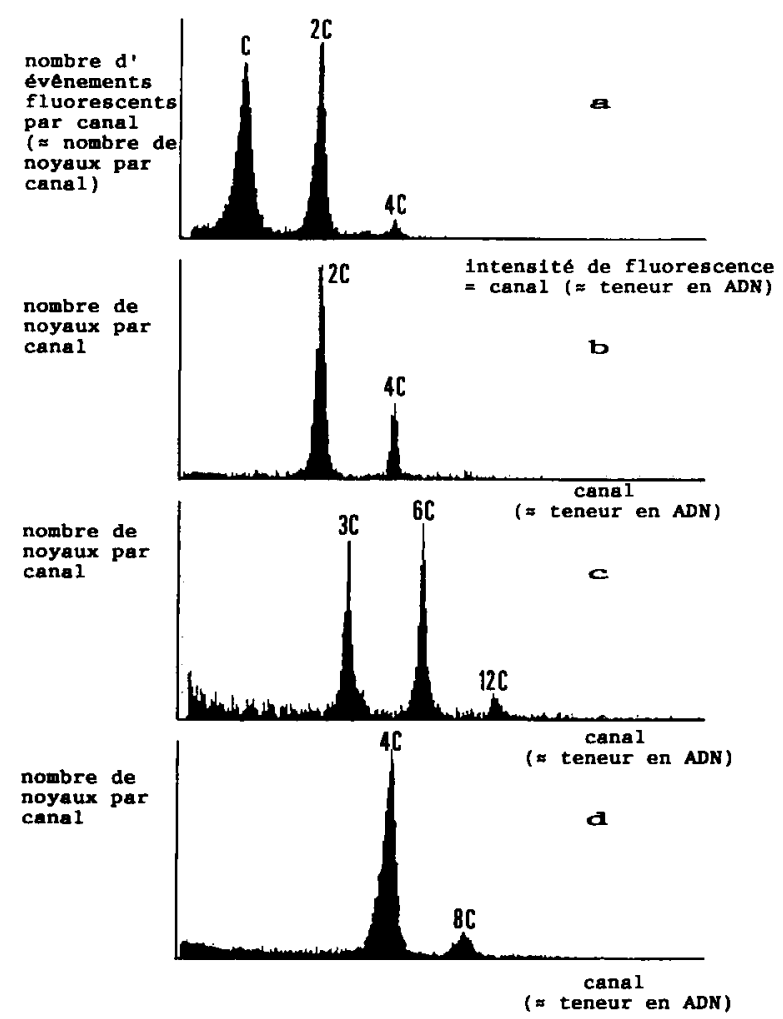

Fig 4. Histrogrammes des intensités de fluorescence (proportionnelles aux teneurs en ADN) observées pour environ 10000 noyaux provenant de feuilles prélevées sur des individus haploïdes (a), diploïdes (b), triploïdes (c) et tétraploïdes (d). L'intensité de fluorescence est mesurée en unité arbitraire (canal). Le premier pic indique le niveau de ploïdie de la plante (noyaux des cellules en phase $\mathrm{G} 1$ ), le second correspond aux noyaux ayant dupliqué leur ADN dans les cellules avant la division (phase G2). Chez les crucifères, les divers tissus peuvent se différencier à partir de cellules en $\mathrm{G} 1$ ou en G2, d'où l'existence simultanée de plusieurs pics sur les histogrammes. ploïdes, tétraploïdes, des individus présentant un niveau de ploïdie supérieur au niveau tétraploïde - en général individus octoploïdes. Des plantes aneuploïdes et mixoploïdes ont également été trouvées.

Une analyse globale des observations dans toutes les descendances d'origine androgénétique permet d'indiquer que la fréquence des individus haploïdes est relativement faible (0 à $12 \%$ selon les descendances), ce qui, a priori, peut paraître surprenant. Des travaux antérieurs (Orton et Browers, 1985 ; Doré et Boulidard, 1988 ; Boucault et al, 1991) ont permis de préciser que le matériel obtenu par culture d'anthères, bien que souvent di- ou polyploïde, était bien homozygote et provenait d'une polyploïdisation précoce de cellules haploïdes. L'apparition de différents niveaux de ploïdie dans des descendances en culture d'anthères serait due à des processus de réplication de I'ADN nucléaire dans les noyaux végétatifs et reproducteurs des microspores au cours de la première semaine de culture in vitro avant le développement embryonnaire (Raquin et al, 1982). Selon Sunderland (1974), l'obtention de polyploïdes pourrait aussi s'expliquer par la fusion de noyaux. Quoi qu'il en soit, nos résultats montrent que les mécanismes conduisant à la polyploïdie chez les choux sont très fréquents et précoces car le pourcentage d'individus mixoploïdes reste faible dans la plupart des descendances (0 à $7 \%$ ).

Pour le chou-fleur comme pour le brocoli, les individus diploïdes (26 à $70 \%$ ) et tétraploïdes (8 à $64 \%$ ) constituent la plus grande partie des descendances avec l'apparition de quelques individus aneuploïdes (0 à 13\%).

En comparant les descendances entre elles, on observe 2 types de répartition des individus bien distincts. Certains génotypes mères conduisent, en effet, à des descendances dans lesquelles les phénomènes de polyploïdisation sont très fréquents. Dans leur descendance, on observe peu ou pas d'haploïdes ( 0 à $7 \%$ ), moins de $50 \%$ de diploïdes (26 à $48 \%$ ), un fort pourcentage de tétraploïdes (50 à 64\%) et un nombre non négligeable de plantes octoploïdes (1 à $5 \%$ ). Pour d'autres génotypes, au contraire, les phénomènes de polyploïdisation semblent moins fréquents. Dans leur descendance, on observe entre 2 et $14 \%$ d'haploïdes, 58 à $70 \%$ de diploïdes, 8 à $26 \%$ de tétraploïdes et, très rarement, des individus octoploïdes. Quelques génotypes ont un comportement intermédiaire. 
Cette situation se retrouve chez le chou-fleur comme chez le brocoli (fig 5).

Le phénomène de polyploïdisation observé en cours de culture semble donc contrôlé par un facteur génétique pour lequel il y aurait une certaine variabilité au sein de l'espèce Brassica oleracea. Des effets physiologiques et de conditions de culture interviennent également dans les mécanismes conduisant à des individus polyploïdes. Ainsi, nous avons pu enregistrer des différences significatives de comportement $\left(\chi^{2}, P<0,01\right)$ en comparant la descendance de 2 boutures issues du même génotype et conduites dans les mêmes conditions (tableau IV). De même, nous notons des différences significatives $\left(\chi^{2}, P<0,01\right)$ en comparant les descendances issues du même génotype cloné, d'une année à l'autre (tableau V). Cependant, ces effets "plante à plante" $\left(\chi^{2}\right.$ maximum observé $=$ $13,34)$ et «année" $\left(\chi^{2} \max\right.$ obs $\left.=20,68\right)$ ne sont jamais, dans nos conditions expérimentales, plus importants que l'effet "génotype" $\left(\chi^{2} \max\right.$ obs $=$ 92,32).

Des modifications du protocole de mise en culture des anthères (chocs thermiques) ou de la composition du milieu de culture (teneur en sac-

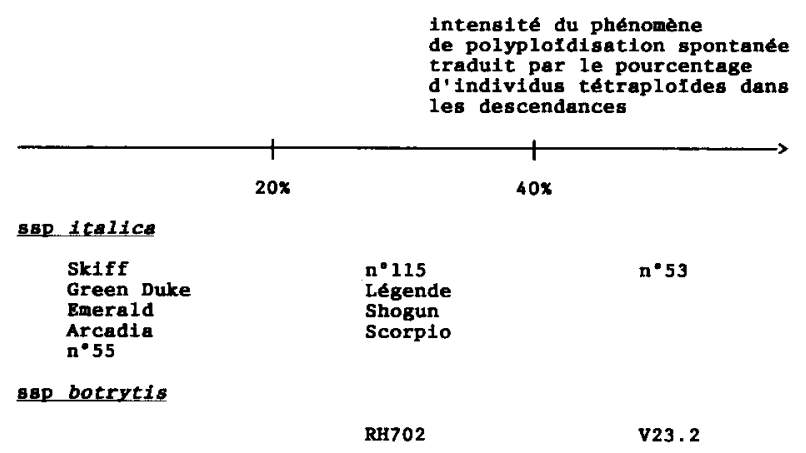

Fig 5. Répartition des génotypes sur une échelle traduisant l'importance du phénomène de polyploïdisation par passage en culture d'anthères. charose ou en nitrate d'argent) semblent sans effet sur le niveau de ploïdie des plantes obtenues (données non présentées). En revanche, l'utilisation d'autres techniques de culture, telles que la culture de microspores (Lichter, 1982) ou de boutons floraux (Yang et al, 1992b), pourrait permettre de réduire le phénomène de polyploïdisation.

Cette polyploïdisation, observée par d'autres auteurs (Doré, 1986 ; Ockendon, 1988) ainsi que les anomalies cytologiques observées sur les lignées HD (Chiang et al, 1989) constituent de nouvelles limites à l'application de la culture d'anthères en sélection des crucifères légumières. Elle rend indispensable un tri précoce des individus dans les populations obtenues par haplométhode et impose de travailler sur des effectifs de départ beaucoup plus larges, les trois quarts de la descendance pouvant être éliminés sur le seul critère "niveau de ploïdie", sauf s'il apparaissait que la polyploïdie puisse avoir un intérêt chez les variétés cultivées (études en cours) en donnant la possibilité d'avoir des hybrides commerciaux triploïdes à partir de plantes diploïdes et tétraploïdes homozygotes.

Ce phénomène de polyploïdisation n'intervient pas uniquement dans les processus de développement androgénétiques mais se retrouve, notamment chez certaines lignées de chou-fleur, dans des phases de multiplication in vitro ou de développement d'embryons obtenus par un processus de fécondation naturelle, ce qui révèle un état diploïde relativement instable pour cette sous-espèce (Chauvin, non publié).

\section{Fertilité des plantes obtenues}

Pour le chou-fleur comme pour le brocoli, les résultats dont nous disposons actuellement tradui-

Tableau IV. Comparaison des fréquences observées dans les différents groupes de ploïdie pour 2 descendances issues d'androgenèse obtenues à partir de 2 boutures d'un génotype initial $\left(n^{\circ} 53\right)$ de brocoli.

Haplö̈des Diploïdes Triplö̈des Tétraplö̈des Octoplö̈des Aneuplö̈des Chimères

$\begin{array}{llllllll}\mathrm{A} & 2 & 58 & 0 & 26 & 0 & 7 & 7 \\ \mathrm{~B} & 0 & 41 & 0 & 51 & 5 & 3 & 0\end{array}$

$\chi^{2}$ obs $=13,34>\chi^{2}$ th $0,99(2)=9,21$ en effectuant des regroupements pour les classes dont les effectifs sont $<5$. 
Tableau V. Comparaison des fréquences observées dans les différents groupes de plö̈die pour 2 descendances de chou-fleur issues d'androgenèse et obtenues à partir du même génotype (V23.2), sur 4 plantes-mères dans chaque cas, l'une en 1989, l'autre en 1990.

Année

Pourcentage d'individus

\begin{tabular}{ccccccc}
\hline Haplö̈des & Diplö̈des & Triploïdes & Tétraplö̈des & Octoploïdes & Aneuploïdes & Chimères \\
\hline 0 & 26 & 6 & 64 & 0 & 0 & 4 \\
7 & 48 & 1 & 37 & 0 & 3 & 4
\end{tabular}

$\chi^{2}$ obs $=20,68>\chi^{2}$ th $0,99(2)=9,21$ en effectuant des regroupements pour les classes dont les effectifs sont $<5$.

sent, à quelques exceptions près, de faibles rendements en graines. Le tableau VI permet de comparer le nombre moyen de graines obtenues par les différentes techniques de pollinisation dans certaines descendances androgénétiques de brocoli. Nous avons également porté sur ce tableau les résultats moyens enregistrés à la même époque sur quelques pieds-mères et leurs descendances obtenues par autofécondation (matériel issu d'un programme de sélection généalogique).
Nous constatons que les rendements en graines sur les lignées HD ou tétraploïdes sont relativement faibles, sauf exceptions, par rapport au matériel de "sélection classique». Cette baisse globale du rendement en graines qui ne semble pas directement liée à une perte de vigueur nette des HD par rapport aux lignées "classiques" (certains HD sont même très vigoureux) pourrait s'expliquer par des irrégularités à la méiose (études en cours). Cet effet de dépression sur la production de graines rend

Tableau VI. Fertilité grainière chez le brocoli : nombre moyen de graines obtenues dans chaque descendance et écart type pour les autopollinisations au stade «bouton" (FA1) réalisées sur 15 fleurs, des autopollinisations au stade "anthèse" (FA2) réalisées sur 15 fleurs, des pollinisations par une plante utilisée comme testeur mâle (FX) également réalisées sur 15 fleurs et pour des pollinisations libres réalisées par des abeilles tout au long de la floraison des génotypes (FXAB).

\begin{tabular}{|c|c|c|c|c|c|}
\hline \multirow[t]{2}{*}{ Matériel végétal } & de ploidie & \multicolumn{4}{|c|}{$\begin{array}{l}\text { Nombre de graines obtenues } \\
\text { à partir de } 15 \text { fleurs ou n fleurs * }\end{array}$} \\
\hline & & FA1 & $F A 2$ & $F X$ & $F X A B^{*}$ \\
\hline $\begin{array}{l}\text { Génotypes issus de } \\
\text { sélection généalogique } \\
\text { (lignées } S 1 \text { et } S 2 \text { issues des } \\
\text { variétés décrites dans le tableau }\end{array}$ & 2n & $44,4 \pm 6,7$ & $11,6 \pm 2,6$ & $85,8 \pm 10,4$ & non fait \\
\hline $\begin{array}{l}\text { Génotypes issus de culture d'ant } \\
\text { Descendance de Green Duke }\end{array}$ & $\begin{array}{l}\text { thères: } \\
2 n \\
4 n\end{array}$ & $\begin{array}{l}0,3 \pm 0,2 \\
0\end{array}$ & $\begin{array}{l}0,02 \pm 0,02 \\
0\end{array}$ & $\begin{array}{l}1,6 \pm 0,8 \\
0\end{array}$ & $\begin{array}{l}11,7 \pm 4,1 \\
\text { non fait }\end{array}$ \\
\hline Descendance de légende & $\begin{array}{l}2 n \\
4 n\end{array}$ & $\begin{array}{l}0,9 \pm 0,6 \\
0\end{array}$ & $\begin{array}{l}0 \\
0\end{array}$ & $\begin{array}{l}3,6 \pm 2,5 \\
0\end{array}$ & $\begin{array}{l}23,5 \pm 9,1 \\
0\end{array}$ \\
\hline Descendance de Skiff & $\begin{array}{l}2 n \\
4 n\end{array}$ & $\begin{array}{l}4,1 \pm 2 \\
0\end{array}$ & $\begin{array}{l}0,4 \pm 0,3 \\
1 \pm 1\end{array}$ & $\begin{array}{l}6,7 \pm 2,3 \\
7,3 \pm 5,9\end{array}$ & $\begin{array}{l}16,2 \pm 7,2 \\
53,3 \pm 29,1\end{array}$ \\
\hline Descendance d'Emerald & $2 n$ & $2,9 \pm 1,6$ & $2,9 \pm 1,8$ & $2,7 \pm 1,5$ & $17 \pm 11,2$ \\
\hline Descendance du $n^{\circ} 53$ & $\begin{array}{l}2 n \\
4 n\end{array}$ & $\begin{array}{l}0 \\
0\end{array}$ & $\begin{array}{l}0 \\
0\end{array}$ & $\begin{array}{l}4,2 \pm 3,7 \\
0,2 \pm 0,2\end{array}$ & $\begin{array}{l}15,8 \pm 10,4 \\
11,1 \pm 11,1\end{array}$ \\
\hline
\end{tabular}


I'usage des HD en sélection particulièrement délicat et constitue un autre écueil pour une utilisation de l'haploïdie comme outil de routine dans les schémas de sélection.

Sur les 172 lignées diploïdes de brocoli obtenues par androgenèse qui ont pu être étudiées dans des conditions climatiques satisfaisantes, seules 50 ont produit des graines (soit 30\%) et, sur ce nombre, seules 11 lignées (soit 6\%) ont présenté des rendements en graines égaux ou supérieurs aux lignées du programme de sélection généalogique. De telles observations avaient déjà été faites sur le même type de matériel (Doré, communication personnelle) et sur chou à choucroute (Doré et Boulidard, 1988).

L'observation des rendements enregistrés lors de pollinisations libres par les abeilles montre toutefois que des quantités relativement importantes de graines peuvent être obtenues sur un certain nombre de génotypes HD. Ainsi, avec ce matériel particulièrement fragile du fait de l'homozygotie, il conviendrait d'adopter des techniques de pollinisation répétées dans le temps qui permettraient de contourner les phénomènes de stérilité partielle pouvant s'établir momentanément pour des raisons d'ordre climatique. Une deuxième solution serait de cultiver ces plants dans des conditions contrôlées favorables au bon développement des organes floraux. Enfin, il sera intéressant de pouvoir comparer les rendements en graines d'un plant directement issu de culture in vitro et les rendements des plantes obtenues dans sa descendance en autofécondation : un retour à un niveau de fertilité satisfaisant pourrait être observé.

L'état polyploïde affecte toujours le rendement en graines après autofécondation. II affecte moins sytématiquement le rendement obtenu après hybridation ou en fécondation libre (tableau VI).

Quoique la comparaison des résultats en autopollinisation et pollinisation par une plante utilisée comme testeur mâle permette de penser que les problèmes de stérilité rencontrés sont essentiellement dus à une absence de fécondation ou à une stérilité des organes femelles, nous avons aussi voulu analyser la viabilité des grains de pollen. La quantité de pollen émise à l'anthèse et la qualité de l'ensemble des pièces florales ont fait également l'objet d'une appréciation qualitative.

On note une grande disparité entre les descendances. En effet, pour les 2 génotypes de départ "Claudia" et "Ninja", on enregistre des taux moyens de viabilité du pollen dans la descendance androgénétique relativement bas, associés ou non à une baisse de la quantité de pollen émise et des fleurs mal conformées. Dans les autres descendances, on retrouve en général des niveaux de viabilité du pollen, des niveaux d'émission de pollen et des conformations de la fleur ne justifiant pas les faibles rendements en graines obtenus.

\section{CONCLUSION}

La difficulté d'utilisation de la technique de culture d'anthères dans le cadre des schémas de sélection des crucifères légumières se retrouve donc à plusieurs niveaux dans l'application de la technique :

- nombre de génotypes "réactifs";

- choix de la méthode pour le génotype mis en culture ;

- développement des embryons en plantules;

- ploïdie des plants obtenus ;

- fertilité des plants obtenus.

Des études complémentaires sur ces différents points doivent être poursuivies car elles ont un intérêt théorique indéniable et pourraient déboucher sur une amélioration globale de la technique.

Si l'on considère que, pour faire un travail de sélection sérieux, il faut observer au minimum 100 lignées issues d'un même génotype de départ avec des effectifs au champ en autofécondation et/ou en test-cross suffisamment élevés, compte tenu des pertes enregistrées au cours des différentes étapes et en se basant sur un rendement moyen en embryons de l'ordre de 50 pour 100 anthères mises en culture, il faut, dans l'état actuel de nos connaissances, mettre en culture environ 6000 anthères pour un seul génotype (fig 6). Cela représente un travail considérable, surtout dans un souci de maintien d'une base génétique assez large au départ qui impose de travailler sur un grand nombre de génotypes. Une possibilité actuellement envisagée est l'utilisation de l'haploïdie pour achever la fixation des génotypes déjà retenus dans les schémas de sélection généalogique, ce qui permet de réduire le nombre de lignées à observer au champ du fait d'une plus grande homozygotie du matériel de départ. Toutefois, il peut également être intéressant d'utiliser la méthode plus précocement pour explorer la variabilité dans les cas 


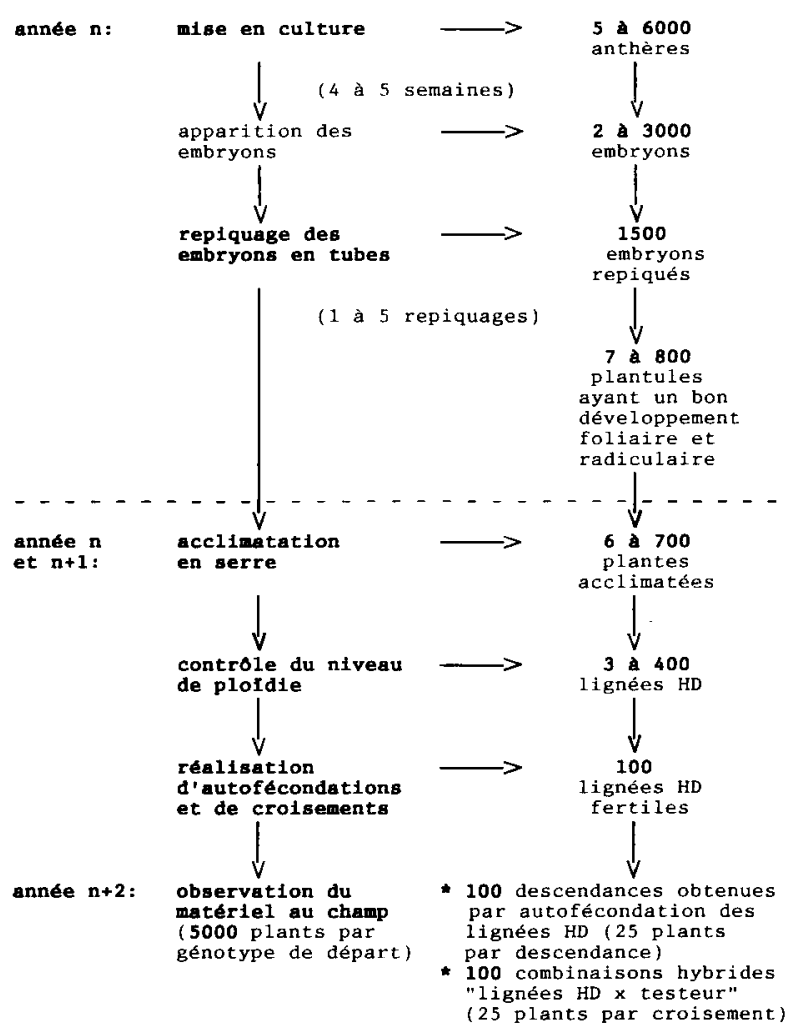

Fig 6. Schéma synoptique des différentes étapes allant de la mise en culture des anthères pour un génotype donné à l'observation de descendances de plantes androgénétiques au champ. Effectifs théoriques pour chacune de ces étapes si l'on souhaite pouvoir observer au champ la descendance d'une centaine de lignées $\mathrm{HD}$ issues d'un génotype donnant 50 embryons pour 100 anthères mises en culture.

de génotypes peu connus des sélectionneurs (évaluation de la "valeur en lignées" en début de sélection).

II faut noter que les résultats présentés ici en ce qui concerne les rendements en embryons sont les plus élevés rapportés à ce jour. Sur chou brocoli, pour le génotype "Green Duke", les résultats enregistrés sont 4 fois supérieurs à ceux obtenus par Arnison et al (1990). Sur chou-fleur, les résultats sont équivalents aux meilleurs rendements obtenus par Phippen et Ockendon (1990).

Compte tenu des effets «plante à plante» et "année» à différents niveaux dans le domaine de l'androgenèse, des progrès ne semblent possibles que par l'acquisition d'une meilleure connaissance de la physiologie de la plantemère. Les travaux de Fabijansky et al (1991) montrant l'apparition de protéines spécifiques au moment du choc thermique dans les anthères des génotypes «réactifs» pourraient constituer les bases d'un travail qui permettrait la détection précoce des états et génotypes «réactifs»; ce pourrait également être une étape vers une meilleure compréhension des mécanismes qui régissent l'aptitude des microspores à évoluer en embryons.

\section{REMERCIEMENTS}

Nous tenons à remercier le Pr Tirilly de l'université de Bretagne occidentale pour nous avoir permis de réaliser les travaux de cytométrie en flux.

\section{RÉFÉRENCES}

Arnison PG, Keller WA (1990) A survey of the anther culture response of Brassica oleracea $\mathrm{L}$ cultivars grown under field conditions. Plant Breed 104, 125-133

Arnison PG, Donaldson P, Ho LCC, Keller WA (1990a) The influence of various physical parameters on anther culture of broccoli (Brassica oleracea var italica). Plant Cell Tissue Organ Cult 20, 147-155

Arnison PG, Donaldson P, Jackson A, Semple C, Keller WA (1990b) Genotype-specific response of cultured broccoli (Brassica oleracea var italica) anther to cytokinins. Plant Cell Tissue Organ Cult 20, 217222

Beyer EM (1976) A potent inhibitor of ethylene action in plants. Plant Physiol 58, 268-271

Biddington NL, Sutherland RA, Robinson HT (1988) Silver nitrate increases embryo production in anther culture. Ann Bot 62, 181-185

Boucault L, Chauvin JE, Margalé E, Hervé Y (1991) Étude de caractères morphologiques et isoenzymatiques sur des plantes issues de culture d'anthères chez le chou-fleur (Brassica oleracea var botrytis). agronomie 11, 727-736

Brown SC, Bergounioux C, Tallet S, Marie D (1991a) Flow cytometry of nuclei for ploidy and cell cycle analysis. In: A laboratory guide for cellular and molecular plant biology (I Negrutiu, G Gharti-Chhetri, eds). Bikhaüser, Bâle, 326-345

Brown SC, Devaux P, Marie D, Bergounioux C, Petit $P X$ (1991b) Analyse de la ploïdie par cytométrie en flux. Biofutur 105, octobre 1991, cahier $n^{\circ} 47,2-16$

Chiang MS, Chong C, Crête R, Fréchette S (1989) Anther-culture derived $2 x$-plants in cabbage (Brassica oleracea L ssp capitata L). I. Meiotic abnormalities. Cytologia 54, 597-603

Doré C (1986) Évaluation du niveau de ploïdie des plantes d'une population de choux de Bruxelles (Brassica oleracea ssp gemmifera) d'origine pollinique. agronomie 6, 797-801

Doré C, Boulidard L (1988) Production de plantes androgénétiques de chou à choucroute (Brassica oleracea $L$ ssp capitata) par culture d'anthères in vitro: comportement des lignées haploïdes dou- 
blées (HD) et leur intérêt comme parents d'hybrides $\mathrm{F} 1$. agronomie 8, 851-862

Duijs JG, Voorrips RE, Visser DL, Custers JBM (1992) Microspore culture is successful in most crop types of Brassica oleracea L. Euphytica 60, 45-55

Fabijansky SF, Altosaar I, Arnison PG (1991) Heat shock response during anther culture of broccoli (Brassica oleracea var italica). Plant Cell Tissue Organ Cult 26, 203-212

Fuller MP, Turton S (1990) Anther culture of winterheading cauliflower. Acta Hortic 280, 329-331

Gamborg OL, Miller RA, Doima K (1968) Nutrient requirements of suspension cultures of soybean root cells. Exp Cell Res 50, 151-158

Heberle-Bors $E$ (1985) In vitro haploid formation from pollen: a critical review. Theor Appl Genet 71, 361 374

Keller WA, Armstrong KC (1983) Production of haploids via anther culture in Brassica oleracea var italica. Euphytica 32, 151-159

Kott LS, Beversdorf WD (1990) Enhanced plant regeneration of microspore-derived embryos of Brassica napus by chilling, partial desiccation and age selection. In: $C R$ du $7^{e}$ colloque international de IIAPTC, Amsterdam, 24-29 juin, poster A7-24

Lichter $R$ (1982) Induction of haploid plants from isolated pollen of Brassica napus. Z Pflanzenphysiol $105,427-434$

Lichter R (1989) Efficient yield of embryoids by culture of isolated microspores of different Brassicaceae species. Plant Breed 103, 119-123

Maheshwari SC, Tyagi AK, Malhotra K, Sopory SK (1980) Induction of haploidy from pollen grains in angiosperms, the current status. Theor Appl Genet $58,193-206$

Ockendon DJ (1985) Anther culture in Brussels sprouts (Brassica oleracea var gemmifera). II. Effect of genotype on embryo yields. Ann Appl Biol 107, 101-104
Ockendon DJ (1988) The ploidy of plants obtained from anther culture of cauliflowers (Brassica oleracea var botrytis). Ann Appl Biol 113, 319-325

Orton TJ, Browers MA (1985) Segregation of genetic markers among plants regenerated from cultured anthers of broccoli (Brassica oleracea var italica). Theor App/ Genet 69, 637-643

Phippen C, Ockendon DJ (1990) Genotype, plant, bud size and media factors affecting anther culture of cauliflower (Brassica oleracea var botrytis). Theor App/ Genet 79, 33-38

Raquin C, Amssa M, Henry Y, de Buyser J, Essad S (1982) Origine des plantes polyploïdes obtenues par culture d'anthères. Analyse cytophotométrique in situ et in vitro des microspores de pétunia et de blé tendre. Z Pflanzenzuecht 89, 265-277

Sunderland N (1974) Anther culture as a means of haploid induction. In: Haploids in higher plants (KJ Kasha, ed). Proc 1st Int Symp, juin 10-14, Univ Guelph, 91-122

Takahata Y, Keller WA (1991) High frequency embryogenesis and plant regeneration in isolated microspore culture of Brassica oleracea L. Plant Sci 74, 235-242

Yang Q (1989) Essais d'induction de plantes androgénétiques chez le chou-fleur et études cytologiques des structures obtenues. Thèse docteur ingénieur, Univ Rennes-1

Yang Q, Chauvin JE, Hervé Y (1992a) A study of factors affecting anther culture of cauliflower (Brassica oleracea var botrytis). Plant Cell Tissue Organ Cult 28, 289-296

Yang Q, Chauvin JE, Hervé Y (1992b) Obtention d'embryons androgénétiques par culture in vitro de boutons floraux chez le brocoli (Brassica oleracea var italica). CR Acad Sci Paris, 314, III, 147-152

Yomoda A, Hinata K (1991) Effects of $\mathrm{CO}_{2}$ gas supply on shoot regeneration in rice callus. Jpn J Plant Breed 41, 41-47 